\title{
ADET-ANANELERIMIZIN FELSEFI YORUMU ÜZERINE
}

\section{Dr. Oruc ABDULLAYEV*}

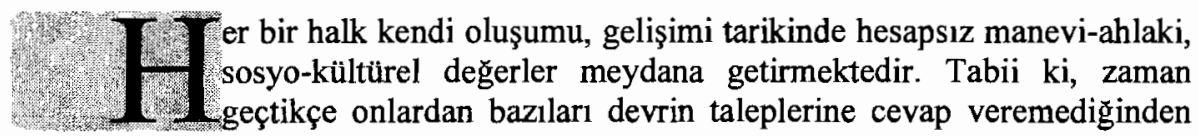
veya çeşitli baskılardan, takiplerden dolayı ortadan kaybolmuş, diğerleri ise halkın manevi hayatı ile ilişkisini kesmemiş, günümüze kadar yaşamını sürdürmüştür. Hatırlatalım ki, genelde halkın yaşamını, tarikini, kulturünü bu manevi değerlerden ayrı tasavvur etmek mümkün olmuyor. Bu değerler içerisinde halkın manevi kültürünü ve karakterini oluşturan adet-ananelerin de önemli rol oynaması dikkat çekmektedir.

Unutmamak gerekiyor $\mathrm{ki}$, adet-ananeler maddi ve manevi medeniyetin özelliklerini kendisinde birleştirmekle birlikte toplumun tarihsel gelişiminin çeşitli basamaklarında toplumun sosyal-manevi gelişmesi sürecinde önemli vasıtalardan biri gibi yakından iştirak etmiştir. Bunu biz çağımızda da görebiliriz. Yani belli manada toplumsal gerçekliğin inkişaf seviyesini gösterebilen, onu yansıtabilen adetananeler aslında insanların hayat tarzınin mükemmelleşmesinde ve gelişmesinde önemli rol oynamaktadır. Bununla bile unutmamak gerekiyor ki, adet-ananeler bazen toplumun yaşamında muhafazakâr (tutucu) bir rol da oynayabilir, yani geçmişin birçok zararlı, gerici manevi-ahlaki, ideolojik unsurları muhafazakârlık ve atalet (sükunet) vasıtaları gibi hala da toplumun hayatında olumsuz rol oynayabilir. Hala gelişime engel bile olabiliyor. Tesadüfi değil ki, toplumun maddi manevi, siyasi, ideolojik problemleri ile birlikte adet-ananelerin değiş̧irilmesi, mükemmelleştirilmesi, geliştirilmesi, yaşam tarzına karmaşık olan etkileri onun olumsuz unsurlarının aradan çıkarılması her zaman uzmanların dikkat merkezinde durmuştur.

Her bir adet-ananenin önemi her şeyden önce onun ifade ettiği, sosyal içerik ve mana ile ilgilidir. Medeniyetin ayrılmaz terkip bölümu olan bu vasıtalar, aynı zamanda halkın sosyal tarihi ve manevi tecrübesi ile de bağl olup, bu tecrubeyi kuşaktan kuşağa aktarmakla birlikte toplumun manevi, ahlaki kültürün yaşam tarzının mükemmelleşmesine etki göstermiş, insanın, aktif bir şekilde hayata müdahale etmesine de sebep olmaktadır.

\footnotetext{
- Azerbaycan Devlet Pedegoji Üniversitesi Felsefe Bölümü Başkanı
} 
Bilim adamları adet ve anane anlamlarının birbirlerine yakın olmasını göstermekle birlikte onların arasında olan farklılıklara da dikkat çekmektedirler. Adetler ihtimal ki, bu Arapça adet kelimesinden olup mana itibarıyla kaide, usul, davranış tarzı, alışkanlık manasına gelip, bir sosyal tarihi hadise gibi insanların hayat tarzına, birlikte yaşamlarında oluşmuş, sabitleşmiş, nesilden nesile aktarılmış yaşam usulü, kaideleri, davranış tarzı, ozzellikle de manevi-estetik idealleri ifade eden, esasen kamuoyuna esaslanan davranışlardır. Adetler insan yaşamında önemli rol oynayan sosyal ve şahsi hadiselerin ifadesidir. Nesillerin birbirine verdigi canlı sembolik bir enfermasyonudur.

Taşıdığı önem ve içerik itibarıyla anane ile adet arasında esaslı bir fark yoktur. Ananeler de tarih süresinde meydana gelmiş, nisbi sabit davranışların, yaşam tarzı ve onun manevi, politik, estetik ideallerin, maddi ve manevi servetlerin, onların ifadesi olan adetlerin, davranışların, yaşayış kaidelerinin bir sözde sosyal tecrübenin birikimidir. Anane sosyal, siyasi, maddi, ekonomik emek, üretim, manevi estetik faaliyeti, maişet kaideleri ve davranış normlarını ifade eder. Onları toplumsal fikir gücüne göre savunabilir, sebitleștirir ve kuşaktan kuşağa aktarabilir. Anane nesiller arasında ilişki, araçlar. Eski nesillerin maddi ve manevi değerlerinin yaşam tarzı ve davranış kaidelerinin, ideallerinin bilgi ve tasavvurlarını, aile, maişet normlarının sistemleştirilip gelecek nesillere ulaştırılması vasıtasıdır. Toplum hayatının ayrılmaz dalıdır.

Tesadufi değil ki, anane manasında bir çok dillerde kullanılan "traditio" kelimesi "ottürülen", "iletilen", "verilen" anlamina gelmektedir. (Dilimizde kullandığımız "anane" sỏzünün Arapça rivayet, masal, hikâyet vasıtasıyla nesilden nesile aktarılan bir hareket, kaide manasında olduğu kaydediliyor.)

Görüldügu gibi "adet" ve "anane" anlayışları manasına göre birbirine yakın anlamlardır. Lakin onlar hiç temin olarak aynı maliyetli anlamlar değildirler.

Ananeler ihata dairesinin genişliğine, sabitlik derecesi ve toplumsal yaşamda daha aktif rol oynaması ile adetlerden farklanıyor. Adetler çoklu tekrarlar ve uzun bir tarihi gelişme sonucunda sabitleşir ve ananeye çevrilirler. Demek ki, içeriği ve sosyal önemi itibariyle adetlerle ananeleri aynileștirmek doğru olmaz. Nitekim, etnografik manada "adet" terimi yerine "anane" kullanmak olmaz. Oyle ananeler var ki, onların hiçbir vakit "adet" adlandırmak mümkün değildir. İnkılabi ananeler, kalbi ananeler, emek ananeleri, nizami ananeler vs. Bu halde demek $\mathrm{ki}$, belli manada adetler ananedir, lakin bütün ananeler "adet" degildir.

Diğer taraftan, o ideolojinin çeşitli forumlanında (siyaset, sanat vs.) adeta bu veya diğer ünlü şahsın adı ile, veya onun esaslandırdığ adı ile bağhı olan belli bir idea, yaratıcllık çizgisini ifade ediyor.

Adet ve ananeler faaliyet dairesine göre de birbirlerinden farklanıyor. Adetlerin faaliyet dairesi çok zaman aile-maişet münasebetleri sahası ile, davranış tarzı ve yaşam tarzı normları ile sinırlanıyor. Adetler insan faaliyetinin üretimden ve sosyal-politik faaliyetten dışarı olan bölümünde daha geniş yayılmıştır. Adetler buna 
göre de esasen insanların maişetindeki (gündelik hayatındaki) ve hayat tarzındaki sabitleşmiş konuların birikim gibi çıkıs ediyor. Bu bakımdan adetler daha çok "maişet ananeleri" anlayışına uygun geliyor. Lakin ananelerin ihata dairesi çok geniştir. Adetler en çok toplumsal şuurun ahlak, din ve hukuk gibi formları ile bağlı olup, esasen maişet münasebetleri anlamında yüze çıktığı halde, ananeler toplumsal şuurun butün forumlarına, ahlaka, hukuka, siyasete, ilme, dine, sanata vs. aynı derecededir.

Toplumsal fonksiyonuna, insanın dünya görüşüne formalaşmasındaki rolüne göre de ananeler adetlere nazaran daha güçlü eğitici bir vasitadır. İlerici ananeler insanların toplumsal, siyasi ve emek faallığına olumlu etki gösterir ve halk tefekküründe en iyi ne varsa hepsini benimser ve nesilden nesile aktarır.

Böylece bir daha kaydetmek gerekin ki, "insan-adet-anane" ilişkileri çok yönlü ve karmaşık sosyal, felsefi problemdendir. Tabii ki, onların çözullmesi her yönlü izahı bundan sonra da uzun bir süre sosyologların, filozofların, sanat adamlarının dikkat merkezinde duracaktır. 